\title{
Formulation of synbiotic soy-based food product with antihypertensive potential
}

\author{
Maja Jurhar Pavlova ${ }^{1 *}$, Kristina Mladenovska ${ }^{2}$, Tanja Petreska Ivanovska², \\ Lidija Petrushevska-Tozi ${ }^{2}$, Petraki Korneti ${ }^{3}$, Vasil Karchev², Nikola Panovski ${ }^{1}$, \\ Milena Petrovska ${ }^{1}$
}

\author{
${ }^{1}$ Institute of Microbiology and Parasitology, Faculty of Medicine, Ss. Cyril and Methodius University, \\ 50 Divizija 6, 1000 Skopje, Republic of Macedonia \\ ${ }^{2}$ Faculty of Pharmacy, Ss. Cyril and Methodius University, St. Mother Theresa 47, 1000 Skopje, Republic of Macedonia \\ ${ }^{3}$ Institute of Medical and Experimental Biochemistry, Faculty of Medicine, Ss. Cyril and Methodius University, \\ 50 Divizija 6, 1000 Skopje, Republic of Macedonia
}

Received: September 2014; Accepted: December 2014

\begin{abstract}
The specific aims of this study were to select the favorable prebiotic for $L$ casei-01 as well as the suitable inoculum of the probiotic for fermented soy with ACE-inhibitory potential. For that purpose the metabolic activity of $L$ casei-01 in soymilk supplemented with $(1.5 \% \mathrm{w} / \mathrm{v})$ prebiotics Fructooligosaccharide (FOS) or oligofructose enriched inulin (Synergy 1) was assessed. The evaluated parameters were: $\mathrm{pH}$, viable cell counts, proteolysis, organic acid production and inhibition of angiotensine converting enzyme activity (IACE). The cell growth of $L$ casei-01 reached the recommended therapeutic level of $9.58 \pm 0.035 \mathrm{log}$ cfu $\mathrm{mL}^{-1}$ for low inoculum samples $(0.005$ and $0.01 \% \mathrm{w} / \mathrm{v})$ and $11.543 \pm 0.13 \log \mathrm{cfu} \mathrm{mL}^{-1}$ for high inoculum samples $(0.075$ and $0.1 \% \mathrm{w} / \mathrm{v})$ regardless of the prebiotic used. The lower $\mathrm{pH}$ during fermentation, faster cell growth and superior proteolysis in Synergy 1 samples indicated better utilization of that prebiotic vs. FOS. The hydrolysis depended on the prebiotic used, showing higher values in Synergy 1 samples. The faster proteolysis was confirmed by SDSPAG electrophoresis. The Mw of polypeptides in the synbiotic end-products were lower than $30 \mathrm{kD}$. The observed values for inhibition of ACE activity were app. 71, 74, 77 and $78 \%$ for inoculum rates of $0.005,0.01,0.075$ and $0.1 \% \mathrm{w} / \mathrm{v}$, respectively.

Based on the results obtained in our study, the prebiotic Synergy $1(1.5 \% \mathrm{w} / \mathrm{v})$ and L. casei-01 at inoculum of $0.01 \% \mathrm{w} / \mathrm{v}$ for low dose and $0.075 \% \mathrm{w} / \mathrm{v}$ for high dose were considered more favorable for the production of synbiotic soy drink with antihypertensive potential.
\end{abstract}

Key words: $L$. casei, Synergy 1, FOS, soy beverage, ACE inhibition

\section{Introduction}

Awareness of complex relationship between food and health has challenged researches to design functional food, food that not only provide basic nutrition but also

\footnotetext{
* Phone: ++389 70349 843;

e-mail: jurharm@yahoo.com
}

has health benefit effects (Gibson and Rastall, 2004). High prevalence of hypertension, one of the major risk factors for coronary heart disease, indicates an urgent need for prevention and choice of therapy. From the standpoint of preventive medicine, soybean-based foods are of great interest because of the evidence that consumption of soy proteins $25 \mathrm{~g}$ per day can lower the risk of cardiovascular dis- 
ease, an indication approved by the U. S. Food and Drug Administration (1999).

Many improvements have been implemented in the processing and methods of preparation of soymilk to improve functionality and usability of soy proteins, among which fermentation of soymilk with probiotic bacteria (Favaro Trindade et al., 2001; Lopez-Fandino et al., 2006).

Soymilk-derived bioactive peptides during fermentation have many beneficial properties, including prevention or delay in the onset of hypertension (Wang and Mejia, 2005; Liu et al., 2011). Well-known mechanism of action of these peptides is based on the inhibition of angiotensin-I converting enzyme (ACE) (Vermeirssen et al., 2004). ACE inhibitory activity of milk products can be enhanced by using the highly proteolytic lactic acid bacteria (LAB). According to Donkor et al. (2005) the use of probiotic strains such as $L$. paracasei, as a part of starter culture in fermented soymilk resulted in a considerable increase in ACE inhibitory activity in vitro compared with the control produced by yogurt culture only (Donkor et al., 2005).

Probiotics differ in their ability to ferment the bioactive fibers. For the production of fermented milk with hypotensive and/or ACE-inhibitory activity, various LAB species have been used, including probiotic Lactobacillus paracasei (Fuglsang et al., 2003; Fitzgerald et al., 2006).

Nowadays, to improve therapeutic effects, dairy foods usually contain probiotics along with prebiotics. Inulin and fructooligosaccharide (FOS) are the premium prebiotics used as safe ingredient supplements to fermented milk (Oliveira et al., 2012), with protective effect on the lactic acid bacteria by stimulating their survival and activity of the end-product during storage (Donkor et al., 2006). Furthermore, they enhance the proteolytic activity and ACEinhibition activity of lactobacilli in fermented soymilk (Yeo and Liong., 2010).

The mixture of probiotics and prebiotics is termed a synbiotic (Gibson and Roberfroid., 1995). The ability of microorganisms to utilize prebiotics is strain- and substrate-specific. Because of that, one of the essentials for good synbiotic formulation is a proper choice of pro- and pre mixture.

The synbiotic mixture of probiotics and prebiotics as well as the composition of a delivery matrix are responsible for variations in the amounts of organic acids, bioactive peptides production and bacterial count in the end-product of fermented functional food. The proteolytic activity should not destroy the product, but it should be able to produce the bioactive peptides in sufficient amount and desired activities. Moreover, it is important for probiotic bacteria to survive the food processing and storage in amount above therapeutic level ranging from $10^{6}$ to over $10^{7}$ or $10^{8}$ cfu $\mathrm{mL}^{-1}$ (Kurmann and Rasic., 1991; Lourens-Hattingh and Viljeon., 2001).

The aim of the study was to prepare fermented soymilk supplemented with prebiotic, in which probiotic viability would be increased, and thus its proteolytic and/or ACE in- hibitory activity enhanced. The effects of prebiotics, FOS and oligofructose-enriched inulin and different inoculum rates of $L$. casei-01, on the metabolic activity and bioactivity of probiotic-fermented soymilk was evaluated in vitro by determination of $\mathrm{pH}$, organic acid production, proteolytic activity and ACE inhibition. In addition, peptide profile of the soy beverage was evaluated.

\section{Material and methods}

\section{Fermentation of soymilk with pro- and pre-biotic}

Two batches of 5 glass flasks, each containing $200 \mathrm{~mL}$ commercial (cholesterol, lactose and gluten free) soymilk (Valsoia Original - VALSOIA SpA, Italy) were supplemented with $1.5 \% \mathrm{w} / v$ prebiotic. Batch 1 was supplemented with oligofructose-enriched inulin (Synergy-1, Orafti ${ }^{\circledR}$ Synergy 1, Orafti-Rue L. Maréchal, Tienen, Belgium) and batch 2 with fructooligosaccharide (FOS, Sigma Aldrich Chemie Gmbh, Germany). The mixtures were heat treated in a water bath at $90{ }^{\circ} \mathrm{C}$ for $30 \mathrm{~min}$, then cooled to 37 ${ }^{\circ} \mathrm{C}$ and aseptically inoculated with $L$. casei-01, commercial name for Lactobacillus paracasei sp paracasei (FDDVS/Lactobacillus casei-01 nu-trish, Chr. Hansen, Hoersholm, Denmark), with different inoculum rates: $0.005 \%$ $w / v(\mathrm{SN} 1$ and FS1), $0.01 \% w / v$ (SN2 and FS2), $0.075 \%$ $w / v(\mathrm{SN} 3$ and FS3), $0.1 \% w / v(\mathrm{SN} 4$ and FS4) and 1\% $w / v$ (SN5 and FS5). SN represents samples supplemented with Synergy 1 and FS samples with FOS. All batches were incubated at $37^{\circ} \mathrm{C}$ until the required $\mathrm{pH}$ of 4.5 was reached; then the fermentation was terminated by cooling at $4{ }^{\circ} \mathrm{C}$. At predetermined time points and at the end of fermentation the aliquots of $30 \mathrm{~mL}$ were taken from each bottle for determination of cell count, $\mathrm{pH}$, proteolysis and organic acid production. The end-products were analyzed for ACE-inhibitory activity.

\section{pH measurements}

Changes in $\mathrm{pH}$ were monitored during fermentation of soymilk at $0,6,12,24,36,48,54 \mathrm{~h}$ and at the end of fermentation using $\mathrm{pH}$ meter (Mettler Toledo Five Easy ${ }^{\mathrm{TM}} \mathrm{FE}$ 20, Switzerland).

\section{Enumeration of viable cells}

Serial dilutions of the samples made in saline water ( $0.9 \%$ w $/ v \mathrm{NaCl}$, Alkaloid, Skopje, Republic of Macedonia) were spread onto MRS agar plates (de Man, Rogosa Sharpe agar, Oxoid, Basingstore, UK) and incubated for 48 $\mathrm{h}$ at $37^{\circ} \mathrm{C}$ in anaerobic conditions. All dilutions were plated in triplicate. Enumeration was performed counting the plates with 25-250 colonies. Mean numbers from two different dilutions were used, and results were expressed as $\log _{10}$ colony forming units per milliliter of fermented milk $\left(\log _{10}\right.$ cfu $\left.\mathrm{mL}^{-1}\right)$. 


\section{Determination of proteolytic activity}

Proteolytic activity was determined as the difference between the free amino $\left(\mathrm{NH}_{3}\right)$ groups in the fermented and unfermented (untreated) soymilk. The $o$-phthaldialdehyde (OPA) method of Church et al. (1983) was used, with some modifications as reported by Donkor et al. (2005). Briefly, $3 \mathrm{~mL}$ of the sample with $3 \mathrm{~mL} 0.75 \mathrm{~N} \mathrm{TCA}\left(\mathrm{CCl}_{3} \mathrm{COOH}\right)$ were vortexed for $1 \mathrm{~min}$, centrifuged at $12000 \mathrm{rpm}, 15$ min and afterwards the supernatants were filtered through $0.45 \mu \mathrm{m}$ membrane filter. The OPA reagent was prepared by mixing $40 \mathrm{mg}$ of OPA (o-phthaldialdehyde, P1378, Sigma Aldrich Chemie Gmbh, Germany) freshly dissolved in $1 \mathrm{~mL}$ methanol $\left(\mathrm{CH}_{3} \mathrm{OH}\right.$, Merck, KGaA Damstadt, Germany), $25 \mathrm{~mL}$ of $100 \mathrm{mM}$ sodium tetraborate decahydrate $\left(\mathrm{Na}_{2} \mathrm{~B}_{4} \mathrm{O}_{7} \times 10 \mathrm{H}_{2} \mathrm{O}\right.$, Alkaloid, Skopje, Republic of Macedonia), $2.5 \mathrm{~mL} \mathrm{20 \%} w / w$ sodium dodecyl sulfate (SDS, $\mathrm{NaC}_{12} \mathrm{H}_{25} \mathrm{SO}_{4}$ Merck, KGaA Damstadt, Germany), $100 \mu \mathrm{L}$ $\beta$-mercaptoethanol $\left(\mathrm{C}_{2} \mathrm{H}_{6} \mathrm{OS}\right.$, Merck, KGaA Damstadt, Germany) and deionized water to final volume of $50 \mathrm{~mL}$. $150 \mu \mathrm{L}$ of filtered sample (supernatant) was mixed with 3 $\mathrm{mL}$ of OPA reagent and after 2 minutes at room temperature $\left(20{ }^{\circ} \mathrm{C}\right)$ the absorbance was measured at $313 \mathrm{~nm}$ by a UV/Vis Spectrophotometer-Agilent 8453 (USA). The proteolytic activity was expressed as absorbance of free amino groups measured at $313 \mathrm{~nm}$ as a difference in absorbance between fermented and non-fermented samples.

\section{Analysis of peptide profile by SDS-PAG electrophoresis}

To determine the proteolytic pattern of soy beverage, samples were centrifuged at $4000 \mathrm{rpm}$ for $20 \mathrm{~min}$ (Rotofix 32A Hettich, Hettich Lab technology, Fohrenstrase 12, D-78532 Tuttlingen, Germany). Then, the supernatants were separated, centrifuged again at $12000 \mathrm{rpm}$ for $20 \mathrm{~min}$ and filtered through $0.45 \mu \mathrm{m}$ membrane filter (MILLEX ${ }^{\circledR}$ HP, Merck Millipore Ltd., Ireland). The protein transition to low molecular peptides was analyzed with horizontal (4$22 \%$ ) gradient gel sodium dodecyl sulfate-polyacrylamide gel electrophoresis (SDS-PAG electrophoresis) (Gorg et al., 1985). When electrophoresis was completed, the protein bands were stained with Coomassie Blue R-250 (Sigma-Aldrich) in methanol ( $\mathrm{CH}_{3} \mathrm{OH}$, Merck, Germany) / water/acetic acid $\left(\mathrm{C}_{2} \mathrm{H}_{4} \mathrm{O}_{2}\right.$, Alkaloid, Skopje, Republic of Macedonia) and then distained in the same solvent. The fractions were identified by using low molecular mass standard mixture. The molecular weights $(\mathrm{Mw})$ of different proteins were as follow: phosphorylase b, $94 \mathrm{kDa}$; albumin, $67 \mathrm{kDa}$; ovalbumin, $43 \mathrm{kDa}$; carbonic anhydrase, $30 \mathrm{kDa}$; trypsin inhibitor $20.1 \mathrm{kDa}$ and $\alpha$-lactalbumin 14.4 kDa (Phatmacia LKB, Biotechnoligy AB, Uppsala Sweden); and high molecular weight proteins as follows: myosin, $212 \mathrm{kDa} ; \alpha_{2}$-macroglobulin, $170 \mathrm{kDa} ; \beta$-galactosidase, $116 \mathrm{kDa}$; transferrin, $76 \mathrm{kDa}$; and glutamic dehydrogenase $53 \mathrm{kDa}$
Determination of produced organic acids in fermented soymilk

The amount of short chain organic acids was determined by high-performance liquid chromatography using a HPLC system apparatus equipped with an ultraviolet detector (Agilent Technologies 1200, Palo Alto, USA). The method used by Wang et al. (2003) was applied with certain modifications. In brief, to determine the concentrations of lactic and acetic acid, $2 \mathrm{~mL}$ of $0.5 \mathrm{M} \mathrm{H}_{2} \mathrm{SO}_{4}$ were added to a 2-mL aliquot of the sample, thoroughly mixed for $30 \mathrm{~s}$ and centrifuged (12 $000 \mathrm{rpm}$ for $15 \mathrm{~min}$ ). The obtained supernatants were filtered through a $0.45 \mu \mathrm{m}$ membrane filter (MILLEX ${ }^{\circledR}$-HP, Merck Millipore Ltd., Ireland). Samples were loaded onto a thermostatically controlled reverse phase column (Discovery HS C 18, $250 \mathrm{~mm}$ x 4.6 mm, $5 \mu \mathrm{m}$, Supelco Park, Bellefonte, PA, USA) set at 40 ${ }^{\circ} \mathrm{C}$ and eluted with $0.005 \mathrm{M} \mathrm{H}_{2} \mathrm{SO}_{4}$ (Alkaloid, Skopje, Republic of Macedonia) at flow rate of $1 \mathrm{~mL} \mathrm{~min}^{-1}$. According to the method applied, the detection wavelength was 210 $\mathrm{nm}$, while identification of lactic and acetic acids was done using their respective standards.

\section{Determination of ACE-inhibitory activity (IACE)}

For the IACE (angiotensin-converting enzyme inhibition) assay the following chemicals were used: the substrate N-[3-(2-furil)-acryloil]-L-phenylalanine-glycyl-glycine (FAPGG, $\mathrm{C}_{20} \mathrm{H}_{21} \mathrm{~N}_{3} \mathrm{O}$, No $7131 \mathrm{Mw} 399.4 \mathrm{~g} \mathrm{~mol}^{-1}$; Sigma-Aldrich, Co. St Louis. Mo. USA), ACE control E (pure ACE from porcine kidney, Trinity Biotech, USA), and Tris buffer (2 hydroxymethyl-1,3-propanediol, No 108382, Mw 121,14 g mol$^{-1}$; Merck, KGaA Damstadt, Germany)

Whey samples from the fermented soymilk were prepared by the following procedure: the end-products were centrifuged (4 $000 \mathrm{rpm}$ for $20 \mathrm{~min}$ at $4{ }^{\circ} \mathrm{C}$ ) and the supernatants were adjusted to $\mathrm{pH} 8$, centrifuged again at $12000 \mathrm{rpm}$ for $20 \mathrm{~min}$ (Biofuge Fresco Heraeus Instruments, USA) and filtered through $0.45 \mu \mathrm{m}$ membrane filter (MILLEX ${ }^{\circledR}$-HP, Merck Millipore Ltd., Ireland).

Whey samples were analyzed by ACE inhibition assay using the method introduced by Tomovska et al. (2011), with slight modifications. Pure ACE from porcine kidney (ACE control E) for ACE solution was used (Vermeirssen et al., 2002). The reaction mixture consisted of a substrate (0.8 $\mathrm{mmol} \mathrm{L}^{-1}$ FAPGG in $50 \mathrm{mmol} \mathrm{L}^{-1}$ Tris buffer, $\mathrm{pH} \mathrm{8.2,}$ chlorides $300 \mathrm{mmol} \mathrm{L}^{-1}$ ), ACE solution (ACE control E freshly reconstituted with $1 \mathrm{~mL}$ deionized water according to the distributor), and sample (supernatant of fermented soymilk) in ratio $10: 1: 1$. The reaction mixture was stirred by flipping the cuvette, which was then placed at $37^{\circ} \mathrm{C}$. During incubation, the absorbance at $340 \mathrm{~nm}$ (with deionized water as a blank) was recorded for $45 \mathrm{~min}$ at exactly 5 min intervals. The absorbance was measured by the UltroSpec 6300pro UV/Visible Spectrophotometer (GE Healthcare, Fisher Scientific, UK Ltd). ACE activity was 
expressed as the slope of the decrease in absorbance at 340 $(\rho A)$ over a linear interval of $45 \mathrm{~min}$. The percentage of ACE inhibition (\%IACE) was calculated from the ratio of the slope in the presence of inhibitor (sample) to the slope obtained in the absence of inhibitor (deionized water instead) using the following equation (Shalaby et al., 2006):

ACE inhibition (\%IACE $)=[1-(\rho \mathrm{A} C-\mathrm{D} / \rho \mathrm{AA}-\mathrm{B})] \mathrm{X} 100$

where A contained substrate solution, ACE solution and deionized water; $\mathrm{B}$, substrate blank contained only substrate solution without ACE solution; $\mathrm{C}$, sample (inhibitor) contained substrate solution, ACE solution and sample; D, sample blank contained substrate solution, sample and deionized water instead of ACE solution.

\section{Statistical analysis}

The results obtained are presented as means \pm SD. Differences were determined by using multiple comparison tests: the ANOVA analyses and Tukey honest significant difference (HSD) test. Correlation analyses between parameters were also made (Statgraph for Windows 3.0). In all tests, a probability level of $\mathrm{p}<0.05$ was used as a significant difference.

\section{Results and discussion}

Changes of pH and viability of L. casei-01 during fermentation of prebiotic soymilk

$\mathrm{pH}$ changes, viable cell counts of $L$. casei- 01 and its metabolic activity were examined to evaluate the fermentation patterns of the prebiotics added.

The $\mathrm{pH}$ changes during fermentation at $37^{\circ} \mathrm{C}$ for all samples are shown in Fig. 1.

The initial $\mathrm{pH}$ of the $L$. casei-01 and prebiotic supplemented soymilk, at time point 0 , for all samples was $6.80 \pm 0.01$. Upon fermentation at $37^{\circ} \mathrm{C}$ for 30 to $62 \mathrm{~h}$, depending on the inoculum rate (Table 1), it reduced by app. $34 \%$, reaching a value of 4.50 . Among the samples fermented with different inoculum rates, both Synergy 1 and FOS supplemented, difference in $\mathrm{pH}$ decline rate was observed. Significant difference $(\mathrm{p}<0.05)$ in $\mathrm{pH}$ decline rate was observed within the first $6 \mathrm{~h}$ of fermentation between the samples supplemented with low $(0.005$ and $0.01 \% \mathrm{w} / \mathrm{v})$ and high $(0.075,0.1$ and $1 \% \mathrm{w} / \mathrm{v})$ inoculum rates. The high inoculum samples showed a continuous decrease in $\mathrm{pH}$ from the very beginning of fermentation, while in the low inoculum samples, a delay of $6 \mathrm{~h}$ was observed. Namely, six hours after inoculation, the $\mathrm{pH}$ value in the high inoculum samples decreased to

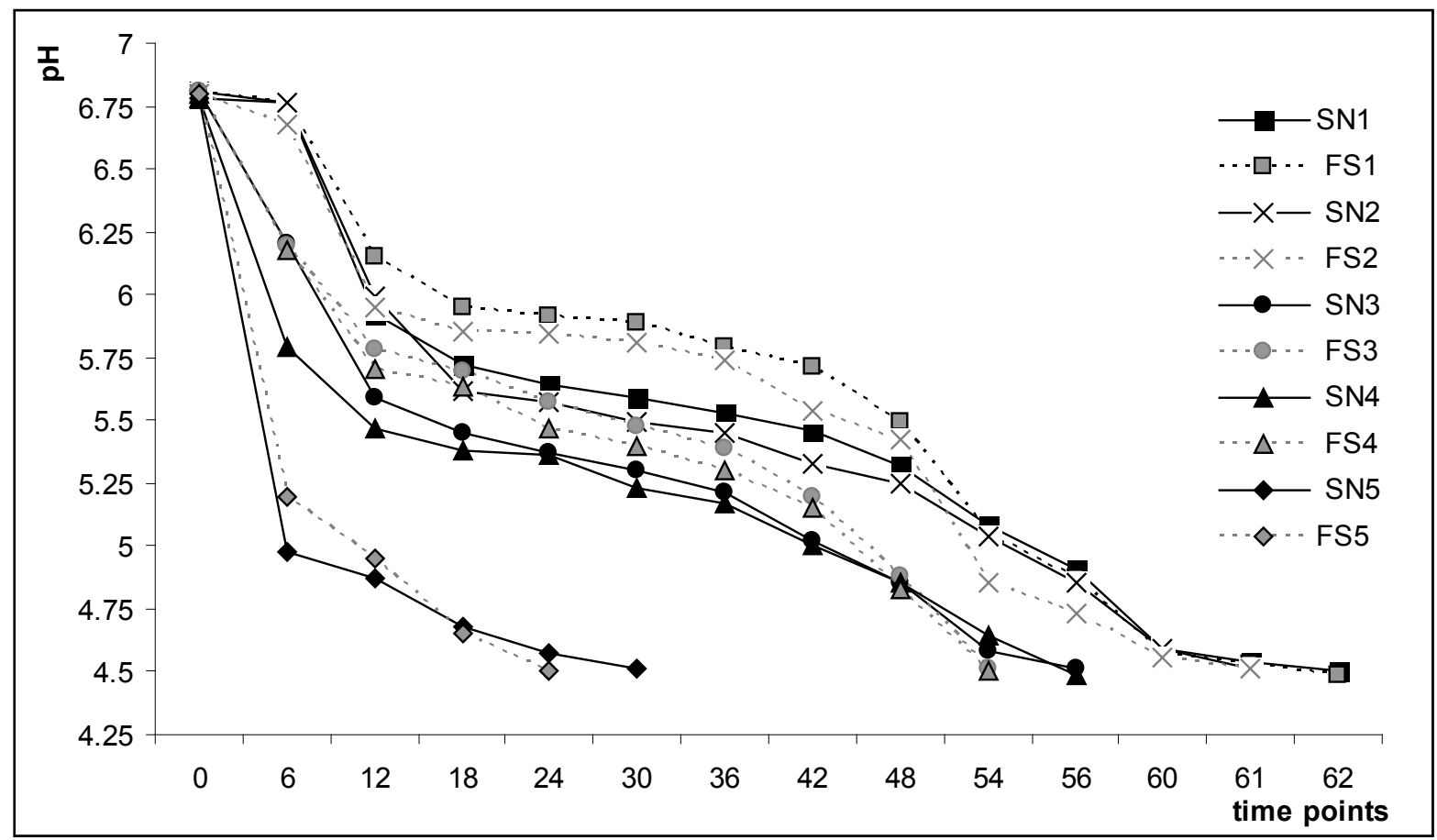

Fig. 1. $\mathrm{pH}$ changes during fermentation of Synergy 1 (SN) vs. FOS (FS) -supplemented soymilk by $L$ casei-01; Time points (hours). (Inoculum rate: $0.005 \% \mathrm{w} / \mathrm{v}, \mathrm{SN} 1 \mathrm{FS} 1 ; 0.01 \% \mathrm{w} / \mathrm{v}, \mathrm{SN} 2 \mathrm{FS} 2 ; 0.075 \% \mathrm{w} / \mathrm{v}$ SN3 FS3; 0.1\%w/v, SN4 FS4; $1 \% \mathrm{w} / \mathrm{v}$ SN5 FS5). 
Table 1. Viability and proteolytic activity of L. casei-01 in end-products

\begin{tabular}{|c|c|c|c|c|}
\hline \multirow{2}{*}{$\begin{array}{c}\text { L. casei- } 01 \\
\text { Inoculum rate } \\
\% \mathrm{w} / \mathrm{v}\end{array}$} & \multicolumn{2}{|c|}{$\begin{array}{c}\text { Cell count } \\
\left(\log _{10} \text { cfu } \mathrm{mL}^{-1}\right)\end{array}$} & \multicolumn{2}{|c|}{$\begin{array}{c}\text { Proteolytic activity } \\
\text { (absorbance at } 313 \mathrm{~nm} \text { ) }\end{array}$} \\
\hline & Synergy 1 & FOS & Synergy 1 & FOS \\
\hline $0.005^{*}$ & $9.59 \pm 0.03^{\mathrm{a}}$ & $9.54 \pm 0.09^{\mathrm{a}}$ & $0.54 \pm 0.02^{\mathrm{a}}$ & $0.31 \pm 0.01^{\mathrm{d}}$ \\
\hline $0.01 *$ & $9.63 \pm 0.18^{\mathrm{a}}$ & $9.58 \pm 0.16^{\mathrm{a}}$ & $0.59 \pm 0.03^{\mathrm{a}}$ & $0.35 \pm 0.07^{\mathrm{d}}$ \\
\hline $0.075^{\#}$ & $11.49 \pm 0.13^{\mathrm{b}}$ & $11.45 \pm 0.06^{\mathrm{b}}$ & $1.11 \pm 0.04^{b}$ & $0.60 \pm 0.07^{\mathrm{a}}$ \\
\hline $0.1^{\#}$ & $11.69 \pm 0.36^{\mathrm{b}}$ & $11.56 \pm 0.21^{b}$ & $1.13 \pm 0.03^{b}$ & $0.67 \pm 0.06^{a}$ \\
\hline $1^{\&}$ & $10.51 \pm 0.34^{\mathrm{c}}$ & $10.25 \pm 0.28^{\mathrm{c}}$ & $3.09 \pm 0.14^{\mathrm{c}}$ & N.D. \\
\hline
\end{tabular}

End-product was obtained after $62 \mathrm{~h} \mathrm{(*),56} \mathrm{h} \mathrm{( \# )} \mathrm{and} 30 \mathrm{~h} \mathrm{( \& )} \mathrm{of} \mathrm{fermentation} \mathrm{(pH} \mathrm{values} \mathrm{4.5).} \mathrm{Results} \mathrm{are}$ expressed as means $\pm \mathrm{SD}$; values are means of duplicates from three separate runs. Means with different lowercase superscript letters are significantly different $(\mathrm{p}<0.05)$. N.D. - not determined.

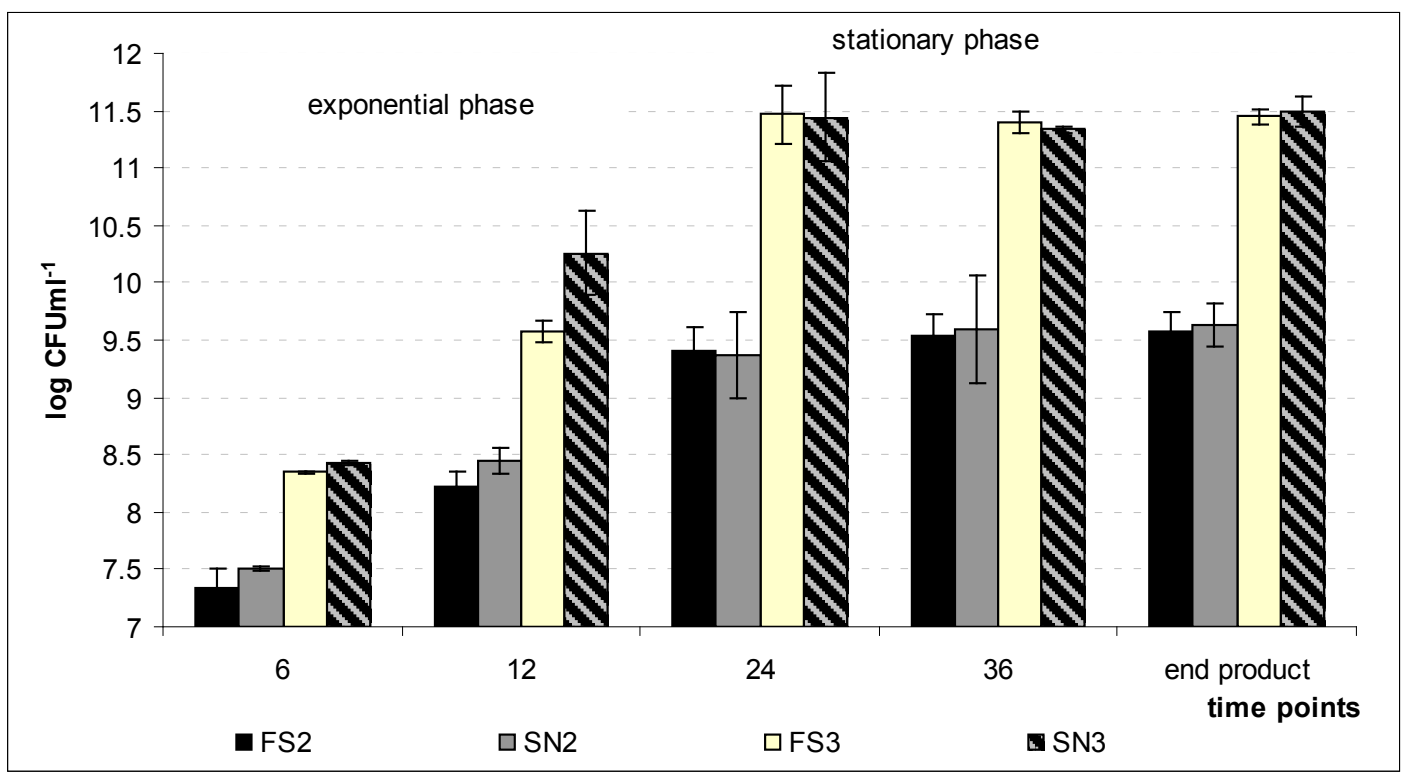

Fig. 2. Growth rate of $L$ casei-01 in soymilk supplemented with Synergy 1 vs. FOS, during fermentation at $37^{\circ} \mathrm{C}$. (Viable cell counts, $\log _{10}$ cfu ml-1 ; time points, hours).

$5.80 \pm 0.58$ (app. 15\%), while in low inoculum supplemented samples, non-significant decrease in $\mathrm{pH}$ was observed, $6.74 \pm 0.04(\approx 1 \%)$, compared to the initial value (Fig. 1). Regarding the prebiotic used, significant difference $(\mathrm{p}<0.05)$ was observed between the low inoculum samples (SN vs. FS) after $12 \mathrm{~h}$ of fermentation, when $\mathrm{pH}$ decline in Synergy 1 supplemented samples showed steeper and longer slope. For example, the $\mathrm{pH}$ value of the SN1 samples after $12 \mathrm{~h}$ of fermentation was $5.92 \pm 0.01$ vs. $6.15 \pm 0.02$ in the FS1 samples. Consequently, throughout the fermentation, $\mathrm{pH}$ values in Synergy 1 supplemented samples were significantly lower than in the FOS enriched samples. Few hours before termination of the fermentation (pH 4.5), the sharper decline (slope) of $\mathrm{pH}$ occurred in FOS samples, with the end $\mathrm{pH}$ value of $4.5 \mathrm{oc}-$ curring app. $60 \mathrm{~min}$ faster than in Synergy 1 enriched samples. A similar decline pattern, with higher rate, was observed for high inoculated samples, probably because of the higher initial biomass of the probiotic (Fig. 1).
The viable cell counts of $L$ casei-01 in all end-products are summarized in Table 1.

At this stage, terminated fermentation ( $\mathrm{pH} 4.5)$, significant difference in cell counts $(p<0.05)$ was observed between the batches with low $(0.005$ and $0.01 \% \mathrm{w} / \mathrm{v})$ and high inoculum $(0.075,0.1$ and $1 \% w / v)$ rates. Obtained values within batches were similar regardless the prebiotics used. As shown in Table 1, in high inoculum batches, the viable cell counts were significantly higher $(p<0.05)$ in both SN and FS samples. Exceptions were the samples inoculated with $1 \% \mathrm{w} / \mathrm{v}$ L. casei-01, where the cell count was lower for $1 \mathrm{log}$ in comparison with the other high inoculum rate samples.

Therefore, cell growth during fermentation was followed in inoculum of $0.01 \% \mathrm{w} / \mathrm{v}$, representing the low inoculum samples (SN2 and FS2), and $0.075 \% w / v$, representing the high inoculum samples (SN3 and FS3). The cell counts were determined at $6,12,24$ and $36 \mathrm{~h}$ and at the end of fermentation (Fig. 2). Time points were cho- 
sen based on changes in $\mathrm{pH}$ values observed during fermentation.

The growth rate of $L$ casei-01 in $\mathrm{SN}$ vs. FS samples was significantly higher during the exponential (log) phase of growth. The exponential phase of L. casei-01 associated with FOS lasted few hours longer regardless of the inoculum rate. Despite the variations observed in log phase, there was no significant difference in viable cell counts of L. casei-01 associated with FOS vs. Synergy 1 in the stationary phase of growth and at the end of fermentation.

Growth rate and viability of probiotics in beverage depends on the strain used, the initial inoculation, incubation temperature, fermentation time, availability of nutrients, and growth promoters (prebiotics). The ability of microorganisms to utilize prebiotics is strain- and substrate-specific (Shah, 2001; Pan et al., 2009). As for the degradation mechanism of inulin-type fructans, it has been reported that L. paracasei spp paracasei degrades inulin type fructans with different degree of polymerization (DP) (Makras et al., 2005). Furthermore, Goh et al. (2007) reported that L. paracasei 1195 has an extracellular enzyme that is cell wall associated and responsible for the degradation of large fractions of FOS and inulin. The results of sugar degradation analysis published by Tsujikawa et al. (2013), clearly indicated that L. paracasei DSM 20020 was capable of degrading the highly polymerized inulin into fructose and sucrose, whereas L. paracasei JCM $8130^{T}$ failed to do so.

L. casei-01 showed a considerable growth with both prebiotics. Still, variations due to different prebiotics and inoculum rates were observed. Based on literature data, we assume that the variations in changes of $\mathrm{pH}$ and viable $L$. casei-01 counts, shown during fermentation, are due to the differences in chain lengths of the prebiotics used. The utilization of inulin-type fructans is strain specific. Both prebiotics were inulin-type fructans, but with different DP. Namely, the DP of FOS varies from 2 to 60 with an average DP of $>10$, while the commercial Synergy 1 mixture is composed of oligofructose (DP 2-8; DP $=4$ ) and longchain inulin fraction (DP 10-60; $\left.\mathrm{DP}_{\mathrm{av}}=25\right)$, known as HP inulin (Roberfroid, 2007).

Our results correspond to those published by Perrin et al. (2002), who showed that shorter chains were the first to be consumed by probiotic bacteria. Furthermore, Aryana et al. (2007) reported lower $\mathrm{pH}$ in a medium with $L$. casei and short chain length oligofructose P95 $\left(\mathrm{DP}_{\mathrm{av}}=5\right)$, compared to long and medium chain inulins. Therefore, the faster growth rate during exponential phase of growth in SN samples compared to FS samples was due to better utilization of short chain oligofructose from Synergy 1 mixture. This was followed by utilization of inulin, but with slower rate than FOS, which resulted in longer fermentation time to determined $\mathrm{pH}$ of app. 4.5 in $\mathrm{SN}$ samples. However, there was no significant difference in cell counts between the end-products with Synergy 1 and FOS, with the corresponding inoculums.

\section{Changes of $\mathrm{pH}$ and viability of L. casei-01 during storage} of prebiotic fortified soymilk

The acidity and cell viability counts were determined after storage at $4{ }^{\circ} \mathrm{C}$ for two and four weeks. The $\mathrm{pH}$ values declined insignificantly with time, while for cell counts a significant change was observed, depending on the prebiotic used. Namely, during two weeks of storage at $4{ }^{\circ} \mathrm{C}$, the cell counts in $\mathrm{SN}$ samples were stable. However, after 4 weeks, they significantly decreased. For example, in samples with inoculum rate of $0.01 \% \mathrm{w} / \mathrm{v}(\mathrm{SN} 2)$ and $0.075 \%$ $w / v$ (SN3), they decreased to $9.10 \pm 0.14$ and $10.45 \pm 0.36$ $\log _{10}$ cfu $\mathrm{mL}^{-1}$, respectively. The results are in agreement with the results obtained by Donkor et al. (2008), who reported a general decline in viable cell counts during storage at $4{ }^{\circ} \mathrm{C}$ from 21 to 28 days for L. acidophilus $L A F$ TI L10, B. lactis LAFTI B94 and L. casei LAFTI L26. The viable cell counts of $L$. casei-01 in FS samples declined significantly after 2 weeks of storage. Namely, in the endproduct with the inoculum rate of $0.075 \% w / v(\mathrm{FS} 3)$, the viable cells decreased from $11.45 \pm 0.06 \log _{10} \mathrm{cfu} \mathrm{mL}^{-1}$ to $9.44 \pm 0.06 \log _{10}$ cfu $\mathrm{mL}^{-1}$.

Nevertheless, the obtained values were above the recommended minimum for probiotic beverages, which characterize the product as functional food. This is in agreement with studies reporting that high chain prebiotics maintain the viability of probiotics at level above the recommended minimum, up to 4 weeks of storage at $4^{\circ} \mathrm{C}$ (Aryana et al., 2007).

\section{Peptide profile}

Probiotics, including L. casei-01, have a complex proteolytic system that enables them to hydrolyze soy proteins and grow in soymilk (Donkor et al., 2007). During hydrolysis the peptides with various biological effects are produced (Gibbs et al., 2004)

Protein patterns in fermented soy products have raised an increased interest because of their health benefit effects, especially in cardiovascular diseases since soy proteins were approved by the Food and Drug Administration in 1999 (FDA 1999). But, not all probiotic/synbiotic soy products are equal. Some variations are based on the probiotics and/or prebiotics used (Erdman et al., 2013). Results, obtained by SDS-PAGE analysis of soymilk protein profile during fermentation, confirmed the proteolytic activity of $L$. casei-01 as well as the influence of associated prebiotics, Synergy 1 and FOS, on the proteolytic rate (Fig. 3).

Approximately $90 \%$ of soy proteins are constituted of two major globulins, $\beta$-conglycinin (7S globulin $\alpha^{\prime}, \alpha, \beta$ subunits; $\mathrm{Mw} \geq 44 \mathrm{kDa}$ ) and glycinin (11S globulin acidic and basic subunits; Mw $<40 \mathrm{kDa}$ ) (Gianazza et al., 2003). SDS-PAGE protein profile of synbiotic soymilk demonstrated that these proteins were gradually degraded during fermentation (Fig. 3). At Lane 2 (FS3 sample, 12 hours of fermentation), the Mw of observed polypeptide bands were $14 \mathrm{kDa}$ and $20 \mathrm{kDa}$ (corresponding to $\mathrm{Mw}$ of glycinin basic 


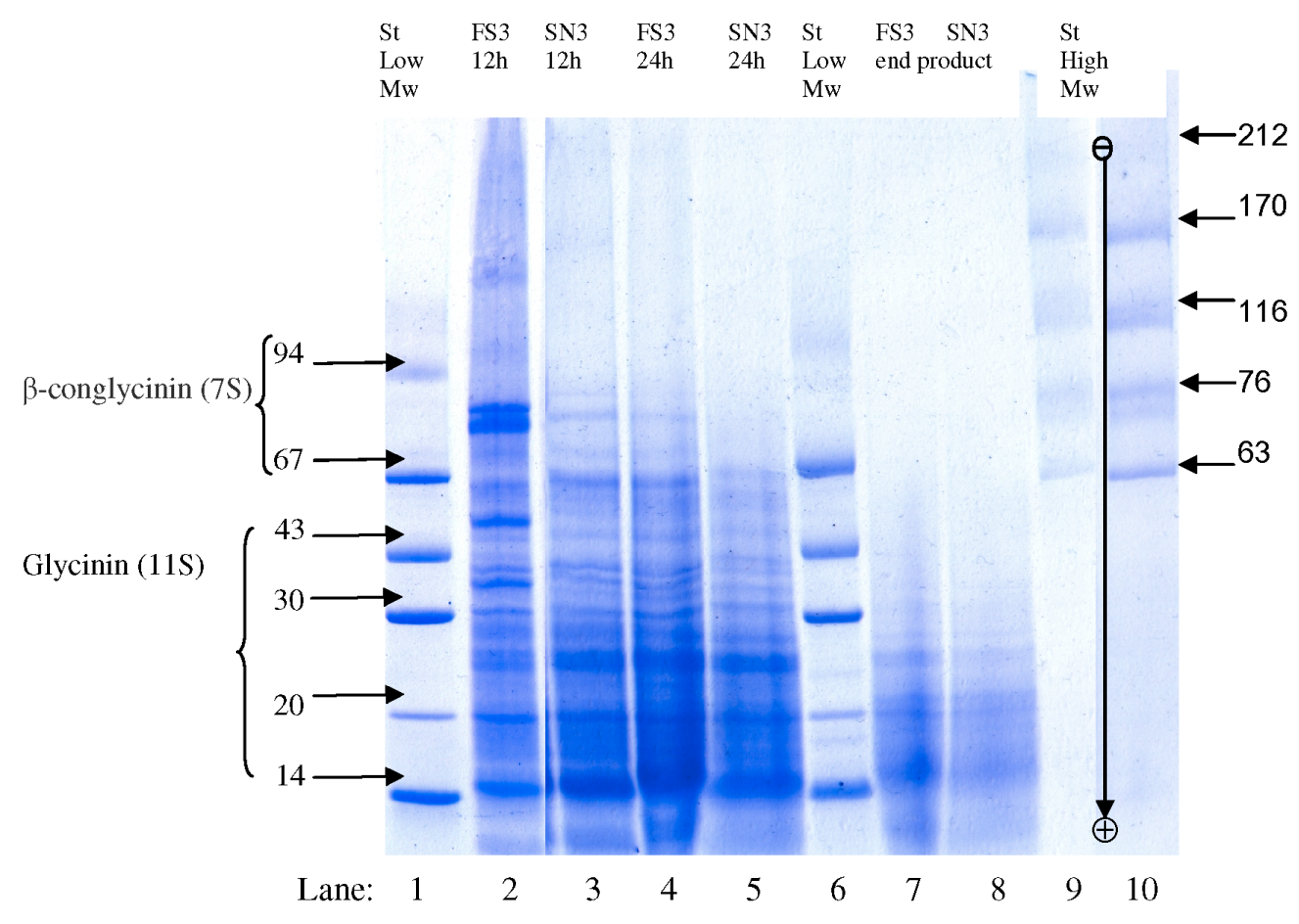

Fig. 3. SDS-PAG electrophoretic profiles of proteins in synbiotic soymilk during fermentation: Lane 1 and $6=$ Low Mw Standard; Lane 9, 10, = High Mw Standard; Lane $2=$ FN3, time point $12 \mathrm{~h}$; Lane $3=$ SN3, time point $12 \mathrm{~h}$; Lane $4=$ FS3, time point $24 \mathrm{~h}$; Lane $5=\mathrm{SN} 3$, time point $24 \mathrm{~h}$; Lane $7=\mathrm{FS} 3$ end-product; Lane $8=\mathrm{SN} 3$ end-product.

subunit), 28-30 $\mathrm{kDa}$ and 38-40 $\mathrm{kDa}$ (corresponding to $\mathrm{Mw}$ of glycinin acidic subunits) and 48-76 $\mathrm{kDa}$ (corresponding to $\mathrm{Mw}$ of $\beta$-conglycinin). At Lane 3 (SN3 sample, 12 $\mathrm{h}$ of fermentation), dominant bands were with Mw corresponding to glycinin subunits. The bands of $\beta$-conglycinin were less intensive, but still existed. Lane 4 (FS3 sample, 24 hours of fermentation) resembled Lane 3. Lane 5 (SN3 sample, $24 \mathrm{~h}$ of fermentation) demonstrated complete degradation of $\alpha^{\prime}, \alpha$, subunits of $\beta$-conglycinin.

As shown in Lane 7 (FS3 sample, end-product) and Lane 8 (SN3 sample, end-product), the $\alpha^{\prime}, \alpha, \beta$ subunits of protein $\beta$-conglycinin (7S) and the acidic chains of glycinin (11S globulin) were completely hydrolyzed. Observed polypeptide bands were with lower $\mathrm{Mw}$ (25, 20 and $14 \mathrm{kDa}$ ). The bands of basic glycinin of the end-products were less intensive compared to bands of samples obtained at 12 and $24 \mathrm{~h}$ of fermentation, indicating incomplete degradation. The bands in Lane 8 were less intensive than in Lane 7 indicating higher proteolysis.

As a consequence of delay in the growth rate of probiotic and $\mathrm{pH}$ drop, there was postponed soy proteins degradation in FS-enriched samples of soymilk.

\section{Proteolytic activity}

As it was confirmed by SDS-PAGE, there was an extended proteolysis of the soymilk proteins during fermentation. The result of protein hydrolysis is an increase in the amount of free amino groups. The OPA-method, based on spectrophotometric detection of released $\mathrm{NH}_{3}$ groups upon hydrolysis, provided a direct measurement of the proteolytic activity. The extent of proteolysis in the end-products is shown in Table 1. The free amino acid content increased along with the enlargement of the inoculum rate. The values obtained for SN samples were significantly higher than those obtained for FS samples, indicating the higher proteolytic activity of $L$. casei-01 in association with the prebiotic Synergy 1. This was confirmed by the observation that the values for proteolysis in FS samples at inoculum rate of $0.075 \% w / v(\mathrm{FS} 3)$ were similar to those of inoculum rate of $0.01 \% w / v$ in $\mathrm{SN}$ samples (SN2).

The $\mathrm{pH}$ in $\mathrm{SN}$ samples was significantly lower than in FS samples throughout the fermentation, resulting in a significantly faster and higher hydrolysis and amount of generated free amino groups in the end-products. Higher proteolysis in SN samples is consistent with the findings of $\mathrm{Ng}$ et al. (2008) who claimed that the proteolytic activity of probiotics is growth-associated. In addition, De Giori et al. (1985) reported that by decreasing $\mathrm{pH}$ of the growth medium, the proteolytic activity is increased, mainly due to the alteration of active structure and hydrogen-ion equilibrium at the active site of the proteolytic enzymes upon $\mathrm{pH}$ changes. 
Optimization of inoculum rate in synbiotic soymilk product

Evaluating the results obtained for $\mathrm{pH}$ change, viable cell counts and proteolytic profile during fermentation of soymilk with $L$. casei-01 in association with FOS and Synergy 1 , respectively, we observed delay in $\mathrm{pH}$ change, biomass yield and proteolysis in FS samples in function of time as well as lower proteolytic activity in FS end-products. Moreover, the results for $\mathrm{pH}$ change during fermentation and proteolytic activity of $L$. casei-01 with inoculum of $0.075 \% w / v$ in association with FOS (FS3) were similar with the results obtained for significantly lower inoculum size, $0.01 \% w / v$, of $L$. casei-01 in association with Synergy 1 (SN4). In addition, although there was no difference in viable cell counts between FS and SN end-products significantly lower cell counts were observed in FS samples after 2 weeks of storage at $4{ }^{\circ} \mathrm{C}$, while SN samples were stable, showing a significant decrease after 4 weeks storage at $4{ }^{\circ} \mathrm{C}$. Based on these findings, Synergy 1 protects the viability of $L$. casei-01 more efficiently than FOS, being more favorable for formulation of functional soymilk beverage.

Therefore, to optimize the inoculum rate of L. casei-01 to ferment the soymilk fortified by Synergy 1, the proteolytic activity in function of time was also determined. The sample with inoculum rate of $0.005 \% w / v$ (SN1) was excluded due to the low proteolytic activity, as well as all FOS fortified samples (Fig. 4).

The decreased $\mathrm{pH}$ during fermentation correlated with the increased proteolytic activity (e.g., $r=-0.885, \mathrm{p}=0.0007$ and $-0.902, p=0.0009$, for SN2 and SN3, respectively).
In order to further optimize the inoculum of $L$. casei-01 for soymilk fermentation fortified by Synergy 1, the production of organic acids (lactic and acetic acids) in function of time was followed in the same synbiotic samples (SN2, SN3, SN4 and SN5).

The results obtained by HPLC showed an increased production of organic acids during fermentation. The concentration of lactic acid was higher than that of acetic acid in all batches (Fig. 5). Similar results were reported by Donkor et al. (2005), who made soy yogurt by fermenting the commercial soymilk using L. acidophilus, B. lactis and L. casei.

Results have shown that the probiotic inoculum of $0.075 \% \mathrm{w} / \mathrm{v}$ used to ferment the soymilk produced lactic and acetic acid in higher quantity compared to the inoculum of $0.01 \% \mathrm{w} / \mathrm{v}$. Using an inoculum of $0.1 \% \mathrm{w} / \mathrm{v}$, the production of lactic acid was not significantly changed (Fig 5a), while the production of acetic acid was increased (Fig. $5 b)$. Acetic acid is an undesirable end-product in fermented soymilk due to its vinegary flavor and unpleasant sensory properties; therefore, the high production of lactic acid over acetic acid is desirable (Donkor et al., 2007; Donkor and Shah, 2008).

This indicates that the inoculum of $0.075 \% w / v$ can be considered optimal for preparation of the fermented soymilk beverage.

\section{ACE-inhibitory activity}

Proteolytic activity is an important attribute for production of peptides that could act as ACE inhibitors. The

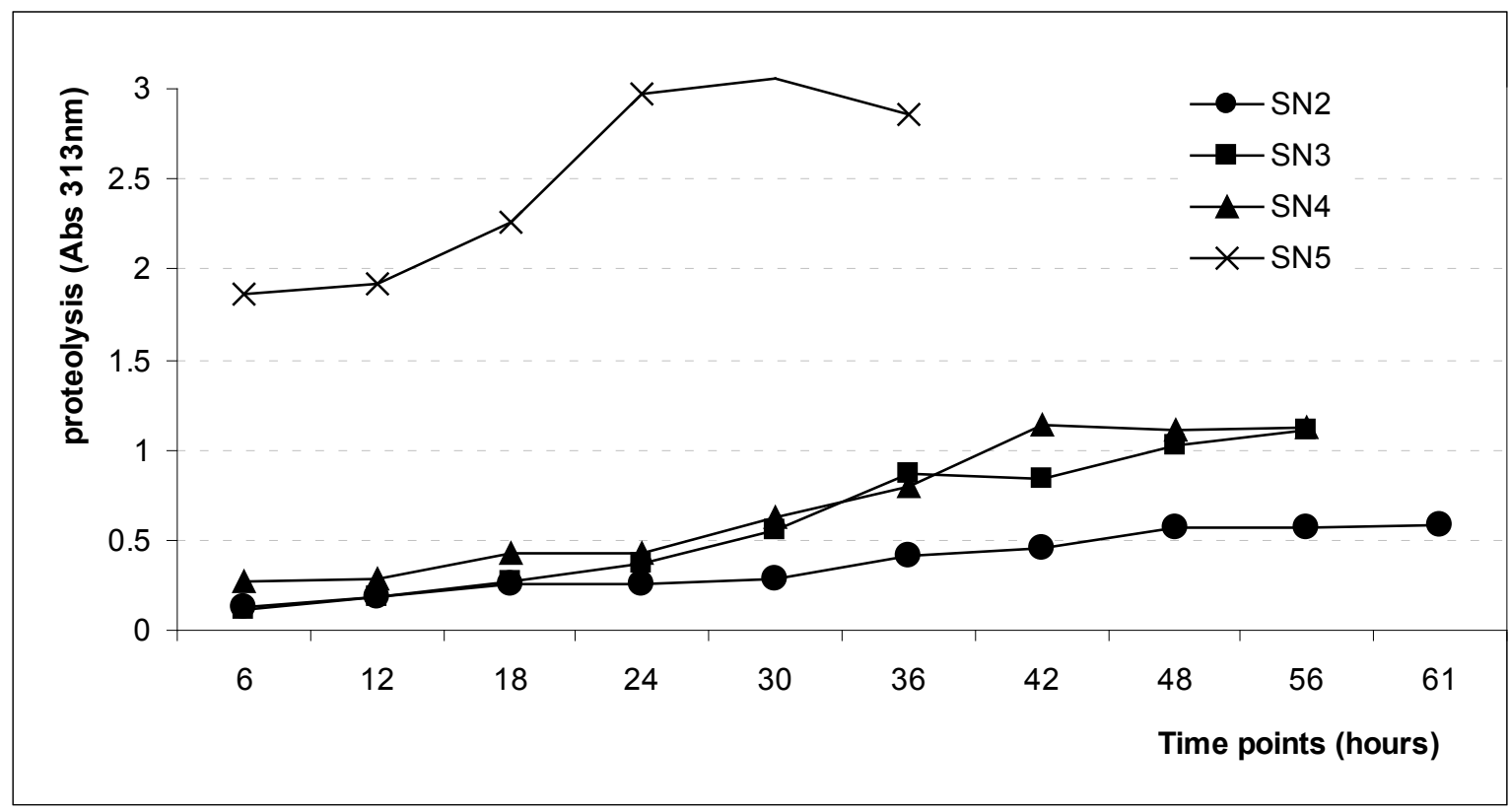

Figure 4. Absorbance vs. time curves for proteolysis during fermentation of Synergy 1-supplemented soymilk by L. casei-01 at different inoculum rates. 

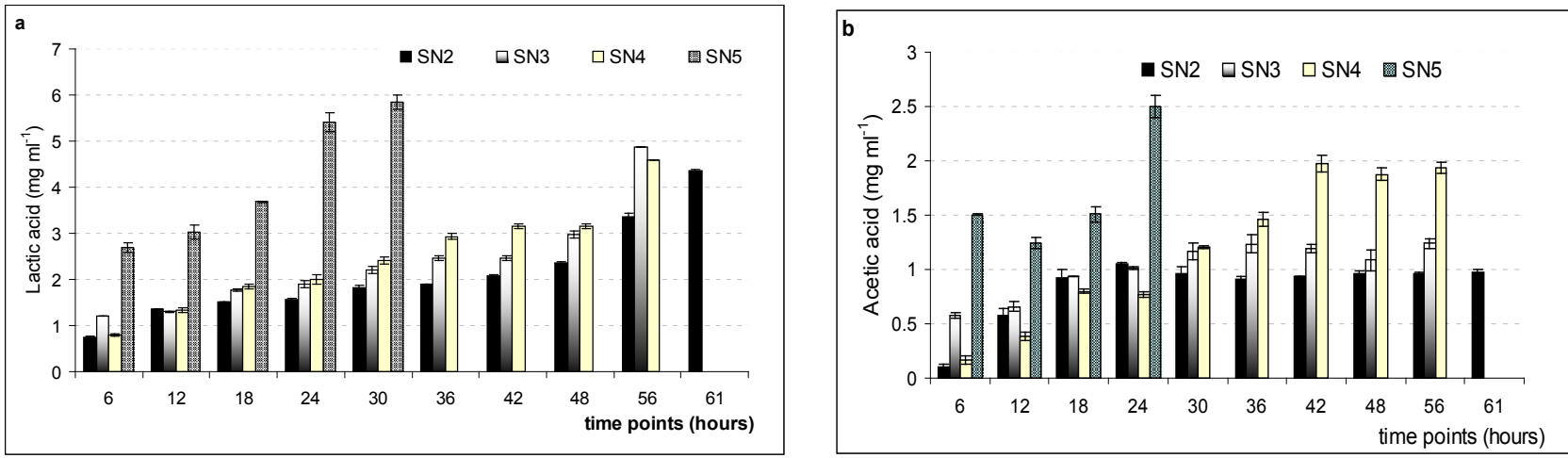

Fig. 5. Production of lactic acid (a) and acetic acid (b) in L. casei-01 and Synergy 1 fortified soymilk during fermentation with different inoculum rates.

development of fermented soymilk containing higher concentrations of released bioactive ACE inhibitors and viable probiotic may deliver health benefits of these functional compounds more efficiently (Donkor et al., 2005). For that purpose, the potential antihypertensive effect of the fermented soymilk beverage in vitro, based on percentage inhibition of the ACE activity was evaluated.

The \%IACE of fermented Synergy 1-fortified endproducts was evaluated in relation to different inoculums of L. casei-01 (SN1, SN2, SN3 and SN4 samples). Curves obtained by spectrophotometric measurements showed a nice linear decrease of absorbance. Sample without fermented soymilk showing $100 \%$ of ACE activity resulted in steeper slope than samples with fermented soymilk. Whole interval from 5 to $45 \mathrm{~min}$ was used for calculating the slope.

For the inoculum of 0.005 (SN1), 0.01 (SN2), 0.075 (SN3) and (SN4) $0.1 \% w / v$ L. casei-01, the \%IACE was calculated as 71, 74, 77.8 and 78.4\%, respectively (Fig. 6).

There was a significant increase in values obtained by increasing the inoculum from 0.005 to $0.075 \% \mathrm{w} / \mathrm{v}$. Values between high inoculum batches were similar. Namely, increasing the inoculum to $0.1 \% \mathrm{w} / v$ the $\% \mathrm{IACE}$ did not change, indicating the inoculum of $0.075 \% \mathrm{w} / \mathrm{v}$ optimal for fermented synbiotic soymilk with antihypertensive potential.

\section{Conclusion}

This study showed that prebiotics FOS and Synergy 1 had different effect on the metabolic activity of $L$. $c a$ sei-01 in soymilk. Both prebiotics provided high viability of $L$. casei- 01 to above therapeutic minimum of $6 \log$ $\mathrm{cfu}_{10} \mathrm{ml}^{-1}$ after preparation and within 4 weeks of storage at $4{ }^{\circ} \mathrm{C}$. But, faster cell growth during fermentation and higher viability during storage was observed in $\mathrm{SN}$ samples. Faster and higher proteolytic activity in samples fortified by Synergy 1 also indicated this prebiotic more favorable for preparation optimal formulation of functional soymilk beverage with $L$. casei-01 as probiotic. Protein profile of samples showed polypeptides with $\mathrm{Mw}$ lower than $25 \mathrm{kDa}$.

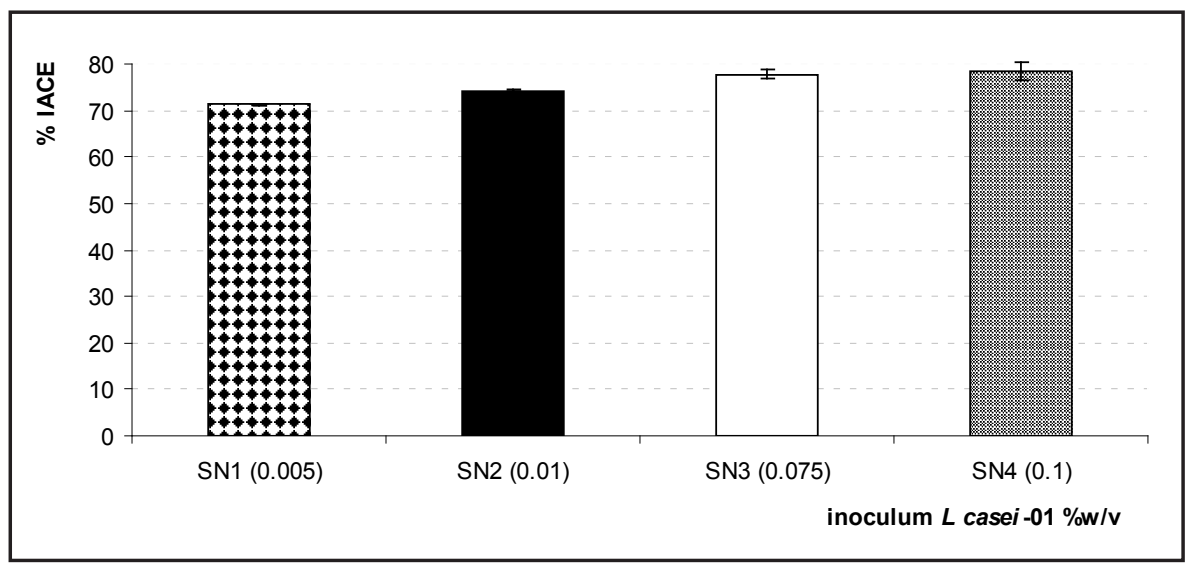

Fig. 6. \%IACE in fermented $1.5 \% w / v$ Synergy 1 -fortified soymilk end-products at different inoculum rate of $L$. casei- 01 . 
The end products exerted appreciable in vitro IACE activity. Based on organic acid production and \%IACE values in Synergy 1 fortified samples, the $L$. case $i-01$ inoculum rate of 0.01 for low dose and $0.075 \% \mathrm{w} / \mathrm{v}$ for high dose synbiotic beverage were chosen for further in vivo studies needed to assess the real antihypertensive potential of our synbiotic product. The development of fermented low-fat synbiotic soymilk with antihypertensive potential and high viable count of probiotic may deliver health benefits to target population with cardiovascular disease risk factors.

\section{Acknowledgments}

This research was financially supported by the Ministry of Education and Science of the Republic of Macedonia (Project No. 13-3583/1). The authors would like to express gratitude to Orafti Beneo Group and to IMCD (UK) for the donation of Orafti ${ }^{\circledR}$ Synergy 1 (L. Maréchal, Tienen, Belgium), and sodium alginate (Protanal 10/60 LS, FMC BioPolymer, USA), respectively.

\section{References}

Aryana, K.J., McGrew, P., 2007. Quality attributes of yogurt with Lactobacillus casei and various prebiotics. LWT Food Sci. Technol. 40, 1808-1814.

Church, F. C., Swaisgood, H. E., Porter, D. H., Catignani, G. L., 1983. Spectrophotometric assay using o-phthaldialdehyde for determination of proteolysis in milk and isolated milk proteins. J. Dairy Sci. 66, 1219-1227.

Donkor, O.N., Hendriksson, A., Vasiljevic, T., Shah, N. P., 2005. Probiotic strains as starter cultures improve angiotensinconverting enzyme inhibitory activity in soy yogurt. J. Food Sci. 70 (8), m375 - m381.

Donkor, O., Nilmini, S., Stolic, P., Vasiljevic, T., Shah, N. P., 2006. Survival and activity of selected probiotic organisms in set-type yoghurt during cold storage. Int Dairy J. 17(6), 657-665.

Donkor, O.N., Henriksson, A., Vasiljevic, T., Shah, N.P., 2007. a-Galactosidase and proteolytic activities of selected probiotic and dairy cultures in fermented soymilk. Food Chem. 104, 10-20.

Donkor, O.N., Henriksson, A., Vasiljevic, T., Shah, N.P., 2007. Rheological properties and sensory characteristics of settype soy yoghurt. J. Agr. Food Chem. 55, 9868-9876.

Donkor, O.N., Shah, N.P., 2008. Production of $\beta$-Glucosidase and Hydrolysis of Isoflavone Phytoestrogens by Lactobacillus acidophilus, Bifidobacterium lactis and Lactobacillus casei in Soymilk. J. Food Sci. 73, M15-M20.

Erdman, J.W., Badger, T.M., Lampe, J.W., Setchell, K.D.R., Messina, M., 2013. Not all soy products are created equal: caution needed in interpretation of research results. J. Nutr. 1229S-1233S.

Favaro Trindade, C. S., Terzi, S. C.,. Trugo, L. C, Della Modesta, R. C., Couri, S., 2001. Development and sensory evaluation of soymilk based yoghurt. Arch. Latinoam. Nutr. 51, 100-104.

Fitzgerald, R.J, Murrsy, B.A., 2006. Bioactive peptides and lactic fermentations. Int. J. Dairy Technol. 59 (2), 118-125.
Food and Drug Administration, 1999. Food labeling health claims: soy protein and coronary heart disease. Final rule, Fed. Register. 64, 57699-57773.

Fuglsang, A., Rattray, F. P., Nilsson, D., Nyborg, N.C.B., 2003. Lactic acid bacteria: inhibition of angiotensin converting enzyme in vitro and in vivo. Antonie van Leeuwenhoek. 83, 27-34.

Gianazza, E., Eberini, I., Arnoldi, A., Wait, R., Sirtori, C. R., 2003. A proteomic investigation of isolated soy proteins with variable effects in experimental and clinical studies. J. Nutr. 133(1), 9-14.

Gibbs, B. F., Zougman, A., Masse, R., Mulligan, C., 2004. Production and characterization of bioactive peptides from soy hydrolysate and soy-fermented food. Food Res. Int. 37, $2,123-131$.

Gibson, G.R., Roberfroid, M., 1995. Dietary modulation of the human colonic microbiota: Introducing the concept of prebiotics. J. Nutr. 125, 1401-1412.

Gibson, G.R., Rastall, R.A., 2004. Functional foods. Bioscience explained. 2, 1-7.

Giori, G.S., Valdez, G.F., Ruiz Holgado, P., Oliver, G., 1985. Effect of $\mathrm{pH}$ and temperature on the proteolytic activity of lactic acid bacteria. J. Dairy Sci. 68, 2160-2164.

Goh, Y.J., Lee, J.H., Hutkins, R.W., 2007. Functional analysis of the fructooligosaccharide utilization operon in Lactobacillus paracasei 1195. Appl Environ Microbiol. 73, 5716-5724.

Gorg, A., Postel, W., Weser, J., Schiwara, H.W., Boesken, H.W, 1985. Horizontal SDS electrophoresis in ultrathin poregradient gerl for the analysis of urinary proteins. Science Tools. 32(1), 5-9.

Kurmann, J. A., Rasic, J.L., 1991. The health potential of products containing bifidobacteria. In R. K. Therapeutic properties of fermented milks. Ed. Robinson, R. K., pp 117-157. ISBN 1-85166-552-8.

Liu, C.F., Tung, Y.T., Wu, C.L., Lee, B-H., Hsu, W-H., Pan, T.M., 2011. Antihypertensive effects of Lactobacillus-fermented milk orally administered to Spontaneously Hypertensive Rats. J. Agric. Food Chem. 59, 4537-4543.

Lopez-Fandino, R., Otte, J., van Camp, J., 2006. Physiological, chemical and technological aspects of milk-protein-derived peptides with antihypertensive and ACE-inhibitory activity. Int. Dairy J. 16, 1277-1293.

Lourens-Hattingh, A., Viljeon, C. B., 2001. Yoghurt as probiotic carrier food. Int. Dairy. 11, 1-17.

Makras, L., Van Acker, G., De Vuyst, L., 2005. Lactobacillus paracasei subsp.paracasei 8700:2 degrades inulin-type fructans exhibiting different degrees of polymerization. Appl Environ Microbiol. 71, 6531-6537.

Ng, K.H., Lye, H.S., Easa, A.M., Liong, M.T., 2008. Growth characteristics and bioactivity of probiotics in tofubased medium during storage. Ann. Microbiol. 58, 477-487.

Oliveiraa, R.P.S., Peregob, P., Oliveiraa, M. N., Convertib, A., 2012. Prebiotic Effect of Inulin on the Growth and Organic Acid Profile of Bifidobacterium lactis in Co-culture with Streptococcus thermophilus. Chem. Eng. Transactions. 27, 277-282.

Pan, X., Wu, T., Zhang, L., Cai, L., Song, Z., 2009. Influence of oligosaccharides on the growth and tolerance capacity of lactobacilli to simulated stress environment. Lett. Appl. Microbiol. 48, 362-367.

Perrin, S., Fougnies, C., Grill, J. P., Jacobs, H., Schneider, F., 2002. Fermentation of chicory fructo-oligosaccharides in mixtures of different degrees of polymerization by three strains of bifidobacteria. Can. J. Microbiol. 48(8), 759-763. 
Roberfroid, M.B., 2007. Inulin-type fructans: functional food ingredients. J. Nutr. 137, 2493S - 2502S.

Robinson (Ed). Therapeutic properties of fermented milks London, UK: Elsevier Applied Food Sciences. pp. 117-158.

Shah, N.P., 2001. Functional foods, probiotics and prebiot ics, Food Technol. 55, 46-53.

Shalaby, S.M., Zakora, M., Otte J., 2006. Performance of two commonly used angiotensin-converting enzyme inhibition assays using FA-PGG and HHL as substrates. J Dairy Research. 73, 178-186.

Tomovska, J., Presilski, S., Gjorgievski, N., Tomovska, N., Qureshi, M.S., Bozinovska, NP., 2013. Development of a spectrophotometric method for monitoring angiotensinconverting enzyme in dairy products. Pak. Vet. J. 33(1), 1418.

Tsujikawa, Y., Nomoto, R., Osawa, R., 2013. Our Difference in Degradation Patterns on Inulin-type Fructans among Strains of Lactobacillus delbrueckii and Lactobacillus paracasei. Biosci Microbiota Food Health. 32(4), 157-165.
Vermeirssen, V., Camp, J., Verstraete, W., 2002. Optimisation and validation of an aniotensin-converting enzyme inhibition assay for the screening of bioactive peptides. J. Biochem. Biophys. Methods. 51, 75-87.

Vermeirssen, V., Camp, J.V., Verstraete, W., 2004. Bioavailability of angiotensin I converting enzyme inhibitory peptides. Br. J. Nutr. 92, 357-366.

Wang, Y. C., Yu, R. C., Yang, H.-Y., Chou, C. C., 2003. Sugar and acid contents in soymilk fermented with lactic acid bacteria alone or simultaneously with bifidobacteria. Food Microbiol. 20, 333-338.

Wang, W., Mejia, E.G., 2005. A new frontier in soy bioactive peptides that may prevent age related chronic diseases. CRFSFS. 4, 63-78.

Yeo, S.K., Liong, M.T., 2010. Angiotensin I-converting enzyme inhibitory activity and bioconversion of isoflavones by probiotics in soymilk supplemented with prebiotics. Int. J. Food Sci. Nutr. 61(2), 161-181.

\title{
Синбиотски прехранбен производ базиран на соја - формулација и определување на антихипертензивниот потенцијал
}

\author{
Маја Јурхар Павлова ${ }^{1 *}$, Кристина Младеновска ${ }^{2}$, Тања Петреска Ивановска ${ }^{2}$, \\ Лидија Петрушевска-Този르, Петраки Корнети ${ }^{3}$, Васил Карчев ${ }^{2}$, Никола Пановски ${ }^{1}$, \\ Милена Петровска ${ }^{1}$
}

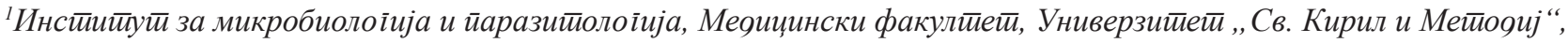

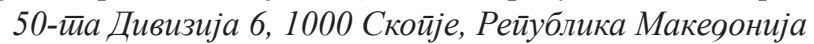

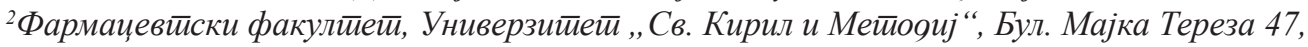 \\ 1000 Скойје, Рейублика Макеоонија

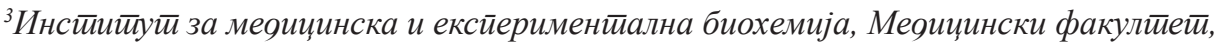

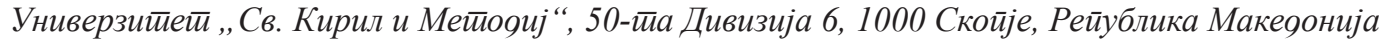

Клучни зборови: L. casei, олигофруктоза-збогатен инулин (Sinergy 1), фруктоолигосахарид (FOS), сојин напиток, АКЕ-инхибиција

Специфични цели на оваа студија беа да се избере пребиотик кој ќе обезбеди поголема виталност на пробиотикот L casei-01 и соодветен инокулум на пробиотикот за подготовка на ферментиран напиток од соја со потенцијал да го инхибира ангиотензин-конвертирачкиот ензим (АКЕ). За овие цели беше подготвен напиток од сојино млеко збогатен со $1.5 \%$ м/8 фруктоолигосахарид или олигофруктоза-збогатен инулин во кој беа додавани различни инокулуми на L casei-01 (0.005-0.1\% M/8). Метаболичката активноста на пробиотикот беше следена преку $\mathrm{pH}$, број на витални клетки, протеолитичка активност, создавање на органски киселини, додека терапевтскиот потенцијал на финалниот напиток преку инхибиција на АКЕ. Во текот на ферментацијата, виталноста на $L$ casei-01 го достигна препорачаното терапевтско ниво, $9,58 \pm 0,035 \log \mathrm{cfu} / \mathrm{mL}$ за примероците со низок инокулум $(0,005$ и $0,01 \% \mathrm{~m} / \mathrm{g})$ и $11,54 \pm 0,13 \log$ $\mathrm{cfu} / \mathrm{mL}$ за примероците со висок инокулум $(0,075$ и $0,1 \%$ m/6), без разлика на користениот пребиотик. За време на ферментацијата, пониска $\mathrm{pH}$, побрз клеточен раст и поизразена протеолитичка активност беше забележана со користењето на олигофруктоза-збогатен инулин што упатува на подобра искористливост на овој пребиотик 
споредено со фруктоолигосахаридот. Хидролитичката активност беше зависна од користениот пребиотик, односно побрза со примената на олигофруктоза-збогатениот инулин, што беше потврдено со SDS-PAGE. Молекуларната маса на полипептидите, добиени со хидролиза на протеините, во синбиотскиот финален продукт беше пониска од $30 \mathrm{kD}$. Инхибицијата на активноста на АКЕ изнесуваше $71,74,77$ и $78 \%$ за инокулуми од $0,005,0,01,0,075$ и $0,1 \%$ m/o, соодветно. Врз основа на овие резултати може да се заклучи дека комбинацијата на олигофруктоза-збогатен инулин $(1.5 \% \mathrm{M} / \mathrm{s})$ и ниско-дозен инокулум од $0,01 \% \mathrm{~m} / 6$ или високо-дозен инокулум од $0,075 \% \mathrm{M} / 6$ на L. casei-01 е оптимална за подготовка на сојин напиток со задоволителен антихипертензивен потенцијал 